\title{
The Impact of Oil Price Shocks on National Income: Evidence from Azerbaijan
}

\author{
Shahriyar Mukhtarov $1,2, *(1)$, Sugra Humbatova ${ }^{3,4}$, Mubariz Mammadli ${ }^{5}$ and Natig Gadim-Oglu Hajiyev $6, *$ \\ 1 Faculty of Economics and International Relations, Vistula University Stoklosy 3, 02-787 Warsaw, Poland \\ 2 Department of Economics, Baku Engineering University, Hasan Aliyev 120, Khirdalan, \\ Baku AZ0101, Azerbaijan \\ 3 Department of Economics and Management, Azerbaijan State University of Economics (UNEC), \\ Istiqlaliyyat Str. 6, Baku AZ1001, Azerbaijan; sugra_humbatova@unec.edu.az \\ 4 Department of World Economy, Baku Engineering University, Hasan Aliyev 120, Khirdalan, \\ Baku AZ0101, Azerbaijan \\ 5 Department of Economy and Business Administration, Azerbaijan State University of Economics (UNEC), \\ Istiqlaliyyat Str. 6, Baku AZ1001, Azerbaijan; mubariz.mammadli@unec.edu.az \\ 6 Department of Regulation of the Economy, Azerbaijan State University of Economics (UNEC), \\ Istiqlaliyyat Str. 6, Baku AZ1001, Azerbaijan \\ * Correspondence: smuxtarov@beu.edu.az (S.M.); naig_hajiyev@unec.edu.az (N.G.-O.H.)
}

Citation: Mukhtarov, S.; Humbatova, S.; Mammadli, M.; Hajiyev, N.G. The Impact of Oil Price Shocks on National Income: Evidence from Azerbaijan. Energies 2021, 14, 1695. https://doi.org/10.3390/en14061695

Academic Editor: Sergio Ulgiati

Received: 1 February 2021

Accepted: 11 March 2021

Published: 18 March 2021

Publisher's Note: MDPI stays neutral with regard to jurisdictional claims in published maps and institutional affiliations.

Copyright: (c) 2021 by the authors. Licensee MDPI, Basel, Switzerland. This article is an open access article distributed under the terms and conditions of the Creative Commons Attribution (CC BY) license (https:/ / creativecommons.org/licenses/by/ $4.0 /)$.

\begin{abstract}
This study investigates the influence of oil price shocks on GDP per capita, exchange rate, and total trade turnover in Azerbaijan using the Structural Vector Autoregressive (SVAR) method to data collected from 1992 to 2019. The estimation results of the SVAR method conclude that oil price shocks (rise in oil prices) affect GDP per capita and total trade turnover positively, whereas its influence on the exchange rate is negative in the case of Azerbaijan. According to results of this study, Azerbaijan and similar oil-exporting countries should reduce the dependence of GDP per capita, the exchange rate, and total trade turnover from oil resources and its prices in the global market. Therefore, these countries should attempt to the diversification of GDP per capita, the exchange rate, and other sources of total trade turnover.
\end{abstract}

Keywords: oil price; income; energy price; SVAR; Azerbaijan

\section{Introduction}

Oil prices in the global market have been fluctuating sharply for several decades [1-3]. As oil is a predominant component which affects global indicators, it is necessary to assess the extent to which GDP per capita, exchange rate, and total trade turnover depend on the effects of oil price shocks. In addition, the importance of the impact of changes in oil prices on the global economy and the recent declining oil prices has given rise to the urgency of this topic and the need for research, which undoubtedly increased interest in studying the impact of oil prices on GDP per capita, exchange rates, and total trade turnover.

Some economists have argued that crude oil is "the most important raw material for many goods and services" and "it has a profound effect on people's lives" [4-7]. In addition to this, researchers also state that "Crude oil attracts more attention than other raw materials" and "it plays an important role in the economy and financial markets" [8-10]. "Due to the importance of crude oil, many investors, governments, enterprises and even researchers have paid great attention to crude oil prices" [11] and "the effects of oil prices and its volatility have a great role in the world economy (although the impact is asymmetric depending on the periods, regions, sectors, the causes of the oil shock and other factors)" [12]. Furthermore, "the impact of world oil prices on macroeconomics has always been a hot and complex topic for scientific research" and "the study of the influence of the fluctuations in oil prices on the economy will be of great practical importance for a long period of time" [13]. Under the influence of some indicators such as transnational policy, 
financial markets in the world, demand and supply of crude oil, the global oil market has become extremely unstable [14]. At the same time, regarding the many features, the world price of crude oil depends on various and complex factors that are interrelated and affect several factors at different times [15].

For many years, economists have agreed that the price of oil is important for the socioeconomic development of countries and the well-being of the population. This view stems from the growing relations between oil prices and the world economy as a result of the rapid development of the social economy [16]. One of the key features of oil prices is that small variations in the prices of crude oil lead to the development in the global economy. However, unusual changes in oil prices send explicit signals to the world's countries in order to identify and resolve many problems in a short period of time. Thus, the price of oil is closely linked with the sustainable development of the global economy [17]. In particular, fluctuations in oil prices could have a significant positive or negative effect on its profitability over time [18].

Changes in oil prices were commonly used in the preparation of forecasts for shortterm growth and unemployment. Although in some cases it is not possible to accurately distinguish the impact on oil importers and exporters, it is probable that changes in oil prices will affect oil importers more quickly.

While lower oil prices will support global economic activity and reduce inflation in the medium term, many oil-exporting countries could find themselves in a difficult position as a result of decreasing oil prices. This is because declining oil revenues affect the budget, and exchange rates are devalued as a result of weakening economic growth and decreasing GDP, as well as per capita GDP. Changes in oil prices increase volatility in financial and foreign exchange markets and it can also affect capital flows. Subsequently, investments in the oil industry in oil-exporting countries may fall sharply.

According to the literature, higher oil prices boost government spending, which ultimately leads to an increase in GDP in oil-exporting countries. Many researchers believe that oil prices have an impact on the growth rate of GDP, as well as per capita GDP. The large number of studies, such as those done by El Anshasy [19], Mendoza and Vera [20], Nwani and Orie [21], Nusair [22], Sadeghi [23], Vohra [24], Alekhina and Yoshino [25], Taghizadeh-Hesary et al. [5], Sultan et al. [26], Balashova and Serletis [27] concluded the positive impact of oil prices on economic growth proxied by GDP or GDP per capita. Considering these points, a positive effect from oil prices to GDP per capita is expected.

Taking into account the above-mentioned facts, it is crucial to evaluate the impact of oil price shocks on macroeconomic indicators. For this purpose, the main aim of this paper is to evaluate the impact of oil price on GDP per capita, exchange rate, and total trade turnover in the case of Azerbaijan.

In this article, the key contribution is to evaluate the influences of oil price shocks on GDP per capita, exchange rate, and total trade turnover, employing time-series data that include both the highest and the lowest oil price periods for Azerbaijan. Moreover, to the best of our knowledge, this is the first study that analyzes the impact of oil prices on GDP per capita as a proxy of national income by using the Structural Vector Autoregressive (SVAR) method. The outcomes of our research paper are remarkable for policymakers of Azerbaijan and similar oil-exporting countries to formulate proper policies in the direction of reducing the dependence of GDP per capita, the exchange rate, and total trade turnover from oil resources and its prices in the global market.

\section{Literature Review}

Oil is not only the most sold product in the world but also the most important energy resource in economic activity [3]. In this regard, changes in its prices always became a research problem. The impact of oil prices on major macroeconomic changes-economic growth, inflation and unemployment is an important economic problem. In general, oil price shocks are detrimental for industrial production and the stability of the economy [28]. Researchers have long been interested in studying oil price volatility and shocks [29]. In 
this context, we reviewed the recent studies analyzing the effect of oil prices on GDP as well as GDP per capita in the case of oil-exporting countries.

El Anshasy [19] analyzed the influence of oil prices on GDP by applying the GeneralizedMethod-of-Moment (GMM) model to the data period of 1970-2004 for 15 oil-exporting countries. The outcomes of estimation revealed a positive oil price effect on GDP. Farzanegan and Markwardt [30] also examined the relationship between oil prices and output growth using the Vector Autoregressive (VAR) method and concluded that oil price has positive impact on output growth in Iran. Mendoza and Vera [20] reached a positive and significant effect from oil price shocks to economic growth employing the Generalized Autoregressive Conditional Heteroscedastic (GARCH) technique for Venezuela. In addition, Nwani and Orie [21] in the case of Nigeria, Nusair [22] in the case of Gulf Cooperation Council (GCC) countries, Sadeghi [23] in the case of 28 oil-exporting countries, Vohra [24] in the case of Gulf Cooperation Council (GCC) countries, Foudeh [31] in the case of Saudi Arabia, Alekhina and Yoshino [25] in the case of non-OPEC oil exporting countries, Taghizadeh-Hesary et al. [5] in the case of oil exporters, Sultan et al. [26] in the case of Indonesia, Balashova, and Serletis [27] in the case of Russia reached the positive effect of oil prices on GDP or GDP per capita.

Additionally, Fezzani and Nartova [32] examined the relationship between oil prices and real GDP. They found a relationship between GDP and oil prices in Iraq. Moshiri and Banihashem [33] investigated the impact of oil prices on economic growth (GDP) for OPEC's six members using data from 1979 to 2009, including Kuwait and Saudi Arabia. The estimation results showed that there is no significant effect of positive oil price shocks on GDP growth in the long-run. Ito [34] utilized the Vector Autoregressive (VAR) technique to evaluate the impact of oil prices on macroeconomic variables in Russia. He found that the rise in oil prices led to an increase in GDP in the short term. Furthermore, employing the Autoregressive Distributed Lag (ARDL) model, Alkhathlan [35] revealed that positive oil prices increased real GDP and negative oil shocks reduced real GDP in Saudi Arabia. Benramdane [36] found that oil prices fluctuations Granger caused GDP per capita in Algeria, applying the Granger Causality test for the period from 1970 to 2012.

Moshiri [37] analyzed the oil price effect on economic growth using data from 1970 to 2010 for nine oil-exporting countries. He concluded that Brent crude oil price (OP) has asymmetric effects on economic growth, employing the VAR method. Charfeddine and Barkat [38] for Algeria and Abdelsalam [39] for MENA countries also revealed that there is asymmetric oil price impact on GDP. Moreover, Benameur et al. [40] investigated the oil price influence on growth rate of GDP in the case of Algeria. The empirical results of the SVAR analysis indicated that oil price has a strong influence on economic growth.

In the case of Azerbaijan, Mukhtarov et al. [41] examined the impact of oil prices on macro-economic variables for the period from January 2005 to January 2019. They found that there is a positive effect of oil prices on economic growth, export, and inflation whereas oil prices have a negative effect on exchange rate. In addition, Mukhtarov et al. [42] revealed a positive impact of oil prices on inflation in the long run by using the Vector Error Correction method (VECM).

\section{Model and Data}

For empirical analysis, annual data ranging from 1992 to 2019 were used for the GDP per capita, Brent crude oil price (OP), exchange rate (EXC) and total trade turnover (TR) in this research. All used variables have been compiled from World Bank national accounts data [43]. GDP per capita is U.S. dollars at constant 2010 prices. The OP is proxied by U.S. dollars per barrel while the exchange rate is proxied by national currency per U.S. dollar. Total trade turnover is the sum of import and export of goods and services (U.S. dollars). All used variables are in logarithmic form. The graphs of variables are given in Figure 1. 
OP



TR

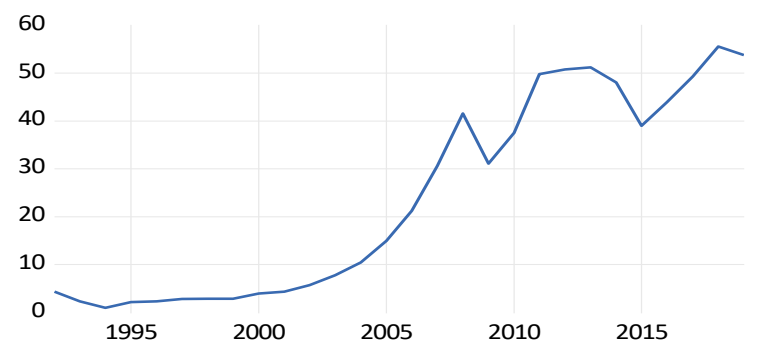

EXC

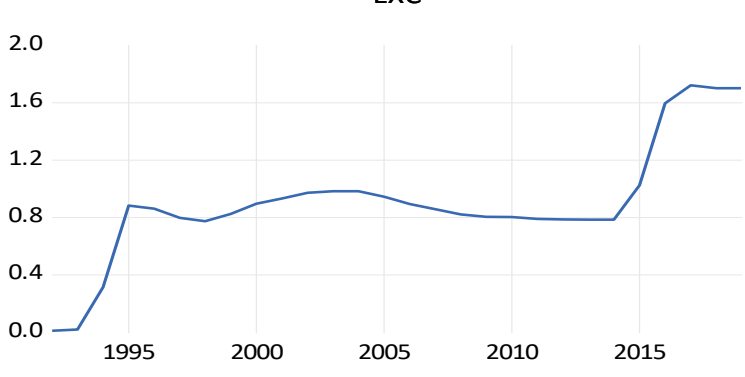

GDP

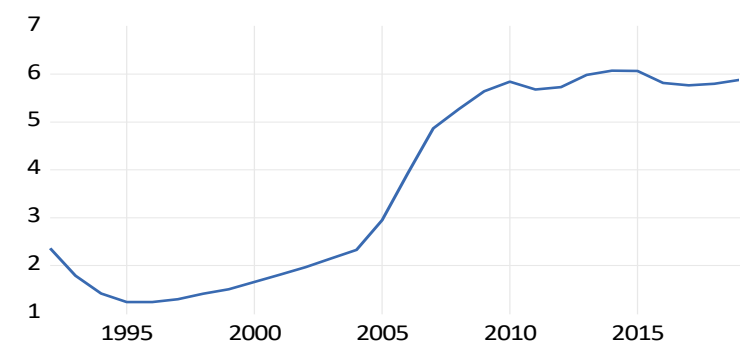

Figure 1. Plots of used variables; $\mathrm{OP}=$ Oil prices (dollars per barrel), $\mathrm{EXC}=$ Exchange rate (Azerbaijani manat per U.S. dollar), TR = Total trade turnover (million dollar), GDP = GDP per capita (thousand dollars); Source: [43].

In this article, we investigate the effect of oil price shocks on exchange rate, total trade turnover, and GDP per capita, utilizing the SVAR method. For the empirical part, we first performed the Augmented Dickey Fuller(ADF) unit root test [44], the Dickey-Fuller GLS (DF-GLS) unit root test [45], and Phillips-Perron (PP) [46] unit root test to check the non-stationarity properties of variables. Next, the impulse-response and variance decomposition together with the SVAR method were used to examine the effect of oil prices on GDP per capita, exchange rate, and total trade turnover. Therefore, the SVAR model can be shown as follows:

$$
A x_{t}=a_{0}+\sum_{n=1}^{k} A_{i} x_{t-i}+\varepsilon_{t}
$$

where $A$ indicates the $4 \times 4$ contemporaneous matrix, $x_{t}=(O P, E X C, T R, G D P$ per capita $)$, $a_{0}$ shows the vector of constant terms, $k$ indicates the optimal lag, $A_{i}$ shows the $4 \times 4$ autoregressive coefficient matrices and $\varepsilon_{t}$ is a vector of mutually and serially uncorrelated structural innovations.

When the elements of $A^{-1}$ are evaluated, we can get the evaluated vector of structural shocks, $\varepsilon_{t}$, since $e=A_{i}{ }^{-1} \varepsilon_{t}$. We can also get the responses of $x_{t}$ to each structural shock. Thus, $e_{t}$ indicates the reduced form VAR innovations. Based on Kilian [47], Kilian and Hicks [48] and Kilian [49], the innovations here are a result of the reduced innovations by imposing recursive exclusion restrictions on $A^{-1}$ as follows:

$$
\mathrm{e}_{\mathrm{t}}=\left\{\begin{array}{c}
e_{t}^{O P} \\
e_{t}^{\text {exc }} \\
e_{t}^{T R} \\
e_{t}^{G D P}
\end{array}\right\}=\left[\begin{array}{cccc}
a_{11} & 0 & 0 & 0 \\
a_{21} & a_{22} & 0 & 0 \\
a_{31} & a_{32} & a_{33} & 0 \\
a_{41} & a_{42} & a_{43} & a_{44}
\end{array}\right]\left\{\begin{array}{c}
\varepsilon_{t}^{O P} \\
\varepsilon_{t}^{e x c} \\
\varepsilon_{t}^{T R} \\
\varepsilon_{t}^{G D P}
\end{array}\right\}
$$

where 0 in the matrix denotes that no expected contemporaneous responses to particular shocks are expected. The non-zero elements $a_{i j}(i=1,2,3,4 ; j=1,2,3,4)$ are the coefficients that indicate the responses of $i$ to the shocks in $j[50,51]$.

This system follows a sequence that goes from exogenous to endogenous, consistent with the variables' respective responses to transient shocks. The restrictions employed to the system in the SVAR method are based on the economic theory. Four theory-based constraints were applied. According to some researchers such as Li et al. [52] and Ade- 
dokun [53] found that oil prices are determined in the global market and should be considered an exogenous variable in an economy. The oil price is the first variable in that it affects all following variables but it is not affected by other variables in the period $t$. Therefore, as Azerbaijan is a small part of global oil market, it does not have the power to affect oil prices, so oil prices are totally external. The exchange rate is in the second row of the recognition matrix. The exchange rate affects all following variables except the first variable. This variable only receives effects from the oil price. The exchange rate is presumed not to respond to any changes in internal variables simultaneously. According to the theory, the decrease in oil prices lead to a decrease in oil revenue and foreign currency inflow. Finally, the lack of foreign currency inflow causes depreciation of national currency. Azerbaijan has experienced a similar situation. Starting in 2014, the sharp decline of oil prices has caused two currency devaluations in Azerbaijan [41,54,55]. The third row of the identification matrix covers total trade turnover. It is presumed that, except for GDP per capita, the total trade turnover is influenced by all factors. The GDP per capita is not subject to any restrictions. The GDP per capita responds to changes in all variables. In conclusion, the oil price is the first variable, followed by exchange rate, total trade turnover, and GDP per capita in this article.

\section{Empirical Results and Discussion}

In the initial step, the stationarity features of the used variables are checked with the ADF, DF-GLS, and PP unit root tests, and the results are depicted in Table 1. All unit root tests confirm that used variables have a unit root in level but are integrated in order one.

Table 1. Outcomes of unit root tests.

\begin{tabular}{|c|c|c|c|c|c|c|c|c|c|c|}
\hline \multirow{2}{*}{ Variable } & \multicolumn{4}{|c|}{ The ADF Test } & \multicolumn{2}{|c|}{ The PP Test } & \multicolumn{4}{|c|}{ The DF-GLS Test } \\
\hline & Level & k & $\begin{array}{c}\text { First } \\
\text { Difference }\end{array}$ & $\mathbf{k}$ & Level & $\begin{array}{c}\text { First } \\
\text { Difference }\end{array}$ & Level & $\mathbf{k}$ & $\begin{array}{c}\text { First } \\
\text { Difference }\end{array}$ & $\mathbf{k}$ \\
\hline$O P$ & -1.411 & 0 & $-4.563^{* * *}$ & 0 & -1.468 & $-4.532^{* * *}$ & -1.260 & 0 & $-4.600^{* * *}$ & 0 \\
\hline EXC & -2.467 & 1 & $-3.307 * *$ & 0 & -1.529 & $-3.234^{* *}$ & -1.562 & 0 & $-3.339 * * *$ & 0 \\
\hline$T R$ & 0.131 & 0 & $-4.312^{* * *}$ & 0 & -0.106 & $-4.517^{* * *}$ & 0.050 & 0 & $-4.325^{* * *}$ & 0 \\
\hline GDP & -1.676 & 1 & $-2.982 * *$ & 0 & -0.414 & $-2.905 *$ & -1.589 & 1 & $-1.721 *$ & 0 \\
\hline
\end{tabular}

Notes: ADF, DF-GLS, and PP refer to the Augmented Dickey-Fuller, Dickey-Fuller GLS and Phillips-Perron tests, respectively. ***,**, and * accordingly refer to null hypothesis rejection at 1\%, 5\%, and 10\% significance levels; critical values are compiled from MacKinnon's table [56].

To estimate the SVAR method, the optimal lag number must be determined. In the beginning, the VAR model was defined for this purpose, with a randomly chosen lag interval and a lag interval determination test applied to the residuals, and it covered the variables of oil price, exchange rate, total trade turnover, and GDP per capita (In addition, the Zivot-Andrew (ZA) unit-root test [57] with structural break was used in order to get more robust results. As the ZA test results show, the series do not reveal a statistically significant break in intercept and trend, except for the TR variable. The test concludes that there is a break in TR in 2009 (See Table A1 in Appendix A). We captured this break with a pulse dummy. Figure A1, which plots variables in normalized scale for comparison, also supports the finding.) All lag-length selection criteria indicate that two lags are an optimal lag. Thus, we estimate the SVAR method with two lags. The results are provided in Table 2.

Additionally, the SVAR residuals with two lags are checked, and all of the results fit the model requirements. The outcomes of the tests are provided in Table 3. 
Table 2. Lag Interval Tests.

\begin{tabular}{cccccccc}
\hline & & \multicolumn{5}{c}{ Information Criteria } \\
\hline Lag & LogL & & LR & FPE & AIC & SC & HQ \\
\hline 0 & -15.79266 & NA & $5.73 \times 10^{-5}$ & 1.583412 & 1.778433 & 1.637503 & -15.79266 \\
\hline 1 & 80.62890 & 154.2745 & $9.40 \times 10^{-8}$ & -4.850312 & -3.875211 & -4.579861 & 80.62890 \\
\hline 2 & 121.4743 & $52.28206^{*}$ & $1.44 \times 10^{-8}$ & $-6.837941 *$ & $-5.082759 *$ & $-6.351128 *$ & 121.4743 \\
\hline 3 & 134.8461 & 12.83701 & $2.44 \times 10^{-8}$ & -6.627691 & -4.092430 & -5.924517 & 134.8461 \\
\hline
\end{tabular}

Note: * shows lag order chosen by the criterion; AIC = Akaike information criterion; FPE = Final prediction error; HQ = Hannan-Quinn information criterion; $\mathrm{LR}=$ serial revised $\mathrm{LR}$ test statistic (each test at $5 \%$ level); $\mathrm{SC}=\mathrm{Schwarz}$ information criterion.

Table 3. The VAR residual diagnostics.

\begin{tabular}{|c|c|c|c|c|c|c|c|c|c|c|c|c|}
\hline \multicolumn{3}{|c|}{$\begin{array}{c}\text { Panel A: Serial Correlation } \\
\text { LM Test }{ }^{\mathrm{a}}\end{array}$} & \multicolumn{2}{|c|}{ Panel B: Stability Test ${ }^{\text {b }}$} & \multicolumn{4}{|c|}{ Panel C: Normality Test ${ }^{c}$} & \multicolumn{4}{|c|}{ Panel D: Heteroscedasticity Test ${ }^{\mathrm{d}}$} \\
\hline Lags & $\begin{array}{c}\text { LM- } \\
\text { Statistic }\end{array}$ & $p$-Value & Modulus & Root & Statistic & $\chi^{2}$ & d.f & $p$-Value & White & $\chi^{2}$ & d.f. & $p$-Value \\
\hline 1 & 20.02867 & 0.218 & 0.9122 & $0.850-0.328 \mathrm{i}$ & Jarque-Bera & 4.073 & 8 & 0.85 & Statistic & 170.5 & 160 & 0.268 \\
\hline 2 & 14.19078 & 0.584 & 0.9122 & $0.850+0.328 \mathrm{i}$ & & & & & & & & \\
\hline 3 & 15.62237 & 0.479 & 0.7696 & $0.158-0.753 \mathrm{i}$ & & & & & & & & \\
\hline 4 & 8.849229 & 0.919 & 0.7696 & $0.158+0.753 \mathrm{i}$ & & & & & & & & \\
\hline
\end{tabular}

Note: ${ }^{a}$ The null hypothesis of LM test refers to no serial correlation in the residuals; ${ }^{\mathrm{b}}$ The results of the VAR stability test indicate all characteristic polynomial roots are inside the unit circle; ${ }^{\mathrm{c}}$ Jarque-Bera refers to the residuals that are normally distributed.; ${ }^{\mathrm{d}} \chi^{2}$ refers to Chi-squared results that show no heteroscedasticity issues in the residuals; d.f. denotes degree of freedom; Estimation period: $1992-2019$.

As the next step, impulse-response and variance decomposition tests were performed with SVAR assumptions to evaluate the impact of oil price shocks on used variables. Firstly, the estimated impulse response function was employed to see the dynamic responses of GDP per capita, exchange rate, and total trade turnover to oil price shocks within the SVAR system.

The responses of GDP per capita, total trade turnover, and exchange rate to onestandard deviation shock to the price of oil for a 12-period forecast horizon are given in Figure 2. The results indicate that the response of exchange rate to an oil price shock is as expected, while the response of exchange rate to oil price shocks is significant and negative during four periods. Therefore, it is found that higher oil prices reduce the exchange rate (national currency appreciation) in four periods. It is worth mentioning that there is an effect on total trade turnover one period after the shock. The response of total trade turnover to oil price shock is only significant for two periods. Obviously, the response of GDP per capita to oil price shock is positive during the initial five periods. It means that a rise in oil prices results in the rise in GDP per capita over time.

Ultimately, a variance decomposition test was also utilized to observe the oil price effect on used economic indicators. Table 4 presents the forecasted variance decomposition analysis for the GDP per capita, exchange rate, and total trade turnover over 12 years of time horizons. The variance decomposition of the EXC concludes that shocks in oil price can explain about $57 \%$ of variation in the EXC. The variance decomposition of TR reveals that the oil price shock accounts for approximately $49 \%$ of the variation in TR. The variance decomposition of GDP per capita in reference to oil price shock explains approximately $51 \%$ of variation in GDP per capita. The outcomes of the decomposition test are in line with the findings of impulse-response functions (IRFs). 

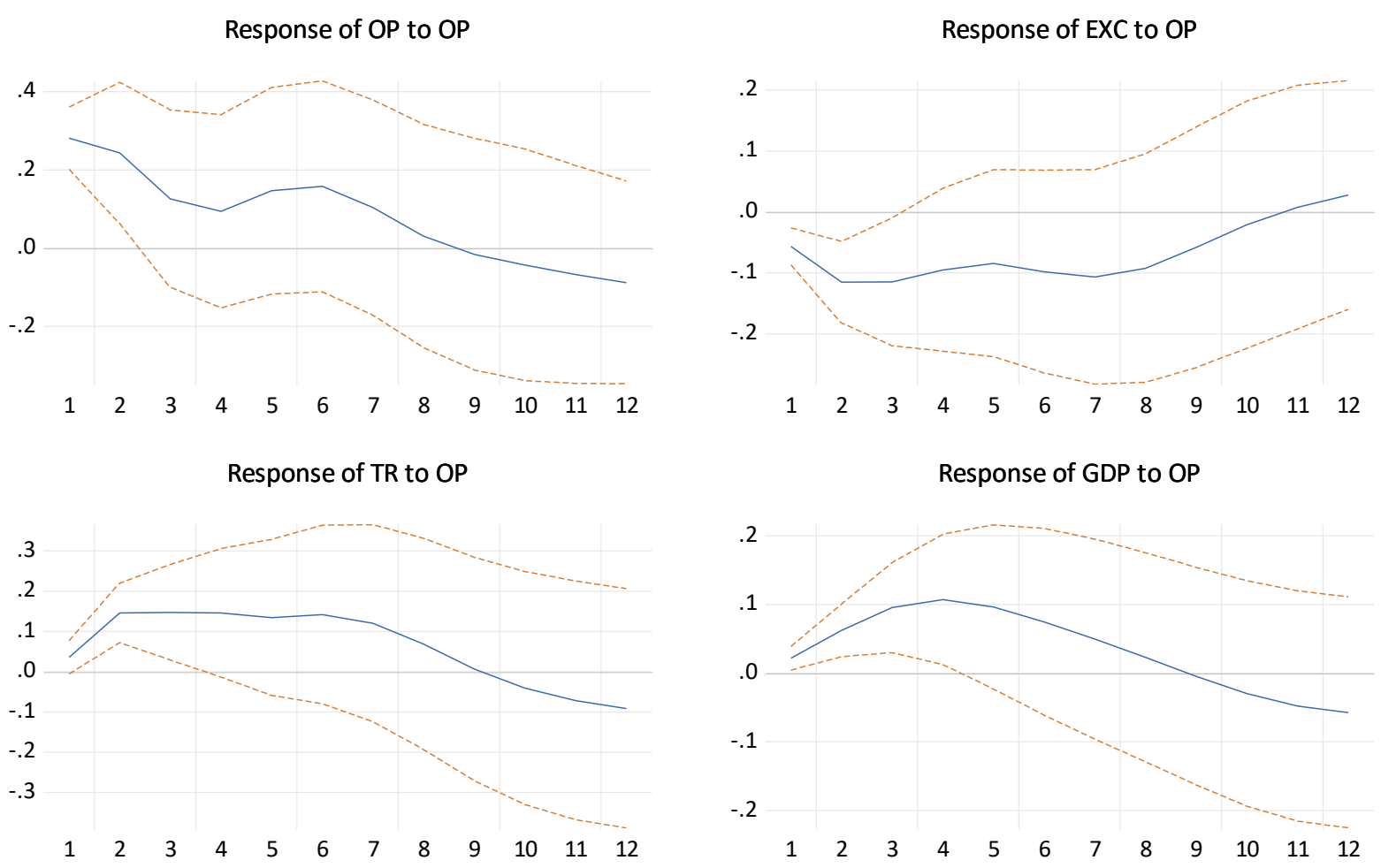

Figure 2. The Results of Impulse-Response Functions.

Table 4. Variance Decomposition: Average of 12 periods.

\begin{tabular}{cccccc}
\hline & SE & OP & EXC & TR & GDP \\
\hline EXC & 0.51 & 57.04 & 24.93 & 2.31 & 15.70 \\
TR & 0.29 & 49.05 & 10.93 & 29.66 & 10.34 \\
GDP & 0.40 & 51.14 & 8.12 & 18.49 & 22.24 \\
\hline
\end{tabular}

Note: Authors' calculation according to results of variance decomposition test.

The estimation results concluded that the effect from oil prices to GDP per capita and total trade turnover was positive, while creating a negative effect on the exchange rate. This implies that a rise in oil price causes a rise in GDP per capita and total trade turnover. It can be explained by the fact that Azerbaijan is one of the important crude oil (37.5 Mt in 2019) and natural gas (24.5 bcm in 2019) producers [58]. It greatly depends on an oil-gas industry [59,60] which approximately accounted for 45\% of GDP in 2019 [61]. In addition, Azerbaijan is a main crude oil (30.8 Mt in 2019) and natural gas (11 bcm in 2019) exporter economy [58]. Hence, it has achieved higher economic growth as a result of its immense stores of crude oil, as well as gas exports that accounted for, on average, over $90 \%$ of overall exports [61,62]. In addition, many studies like El Anshasy [19] in the case of 15 oil-exporting countries, Mendoza and Vera [20] in the case of Venezuela, Nwani and Orie [21] in the case of Nigeria, Nusair [22] in the case of GCC countries, Sadeghi [23] in the case of 28 oil-exporting countries, Vohra [24] in the case of GCC countries, Alekhina and Yoshino [25] in the case of non-OPEC oil exporting countries, Taghizadeh-Hesary et al. [5] in the case of oil exporters, Sultan et al. [26] in the case of Indonesia, Balashova and Serletis [27] in the case of Russia reached similar results. However, the obtained negative effect of oil prices on the exchange rate coincides with the outcomes of Mukhtarov et al. [41] and economic theory. Two points can be specifically seen when comparing our findings to the results of Mukhtarov et al. [41]. First, the effect of oil prices on the exchange rate is negative in both studies. Second, Mukhtarov et al. [41] used the vector error correction method for estimation and did not apply theory-based restrictions. Therefore, the increase in oil prices causes rise in oil revenue and foreign currency inflow. Consequently, the vast 
foreign currency inflow decreases the exchange rate (a national currency appreciation). As result, the increase of national currency leads to a rise in imports.

In addition, it is worth stating that our findings in this paper, particularly those regarding oil price and exchange rate, imply Dutch Disease-related consequences, and are in line with the findings of the previous studies [63-65] and inter alia.

\section{Conclusions}

This article examines the influence of oil price shocks on GDP per capita, exchange rate, and total trade turnover for an Azerbaijani case study. For this purpose, the SVAR method was applied over the period of 1992 to 2019. The estimation results revealed that oil prices have a positive impact on GDP per capita and total trade turnover, which creates a negative impact on the exchange rate in the case of Azerbaijan. Thus, oil prices have a stronger impact on the exchange rate and GDP per capita. However, differing from them, it has little effect on overall trade. Based on these, the following can be specifically recommended:

- More efficient and rational use of foreign exchange reserves in the future, taking into account the greater dependence of the national currency on oil prices. Thus, in the process of regulating the exchange rate of the national currency, it would be better to develop a plan of alternative measures to foreign exchange interventions that deplete foreign exchange reserves (securities and discount rate policy).

- Increase the stimulation of exports of non-oil products and further accelerate the substitution of oil exports with non-oil exports in order to further reduce the impact of oil prices on total trade turnover (increase in import through appreciation of national currency).

- Considering the significant and positive impact of oil prices on GDP per capita, giving preference to economic areas which are more stable and sustainable to the impact of changes in oil prices.

Moreover, the results of this article also conclude that Azerbaijan as an oil-exporting country is highly sensitive to shocks in oil prices. Therefore, it emphasizes the usefulness and importance of the implementation of economic policies which regulate the country in a way that eliminates the economy's dependence on oil production and direct the country to more sustainable growth. In this perspective, Azerbaijan and similar oil-exporting countries must consider how external oil price shocks impact their economies and how they are able to apply policy tools to develop a private sector-oriented, diversified, less oil-dependent economy.

Author Contributions: All authors contributed equally to all aspects of the research reported in this article. All authors have read and agreed to the published version of the manuscript.

Funding: This research received no external funding.

Conflicts of Interest: The authors declare no conflict of interest. 


\section{Appendix A}



Figure A1. Plots of the used variables, normalized scale.

Table A1. Zivot-Andrew Unit tests results.

\begin{tabular}{cccc}
\hline Variables & Both & Int & Trend \\
\hline op & -3.753 & -4.379 & -3.436 \\
exc & -30.218 & -28.170 & -25.901 \\
tr & $-5.304^{* * *}$ & $-4.709^{* *}$ & $-5.588^{* *}$ \\
gdp & -9.828 & -6.632 & -4.034 \\
\hline
\end{tabular}

Notes: both = break in intercept and trend; int = break in intercept; trend = break in trend; ${ }^{* * *}=$ rejection of null at $1 \%$ significance level; ${ }^{* *}=$ rejection of null at $5 \%$ significance level; null hypothesis of the test states unit root with structural break in a specified part (intercept, trend, or both) of the variable.

\section{References}

1. Guo, J.-F.; Ji, Q. How does market concern derived from the Internet affect oil prices? Appl. Energy 2013, 112, 1536-1543. [CrossRef]

2. Ji, Q.; Fan, Y. How does oil price volatility affect non-energy commodity markets? Appl. Energy 2012, 89, 273-280. [CrossRef]

3. Peng, J.; Li, Z.; Drakeford, B.M. Dynamic Characteristics of Crude Oil Price Fluctuation-From the Perspec-tive of Crude Oil Price Influence Mechanism. Energies 2020, 13, 4465. [CrossRef]

4. Le, T.-H.; Chang, Y. Effects of oil price shocks on the stock market performance: Do nature of shocks and economies matter? Energy Econ. 2015, 51, 261-274. [CrossRef]

5. Taghizadeh-Hesary, F.; Yoshino, N.; Rasoulinezhad, E.; Chang, Y. Trade linkages and transmission of oil price fluctuations. Energy Policy 2019, 133, 110872. [CrossRef]

6. Le, H. Dynamics between energy, output, openness and financial development in sub-Saharan African countries. Appl. Econ. 2016, 48, 914-933. [CrossRef]

7. Roman, M.; Górecka, A.; Domagała, J. The Linkages between Crude Oil and Food Prices. Energies 2020, 13, 6545. [CrossRef]

8. Ghalayini, L. The Interaction between Oil Price and Economic Growth. Middle Eastern Financ. Econ. 2011, 13, 127-140.

9. Nazir, S.; Hameed, T. Impact of Oil Price and Shocks on Economic Growth of Pakistan: Multivariate Analy-sis (Sectoral Oil Consumption). Bus. Econ. J. 2015, 6, 1-11.

10. Zhu, H.; Su, X.; Guo, Y.; Ren, Y. The Asymmetric Effects of Oil Price Shocks on the Chinese Stock Market: Ev-idence from a Quantile Impulse Response Perspective. Sustainability 2016, 8, 7. [CrossRef]

11. Li, T.; Hu, Z.; Jia, Y.; Wu, J.; Zhou, Y. Forecasting Crude Oil Prices Using Ensemble Empirical Mode Decom-position and Sparse Bayesian Learning. Energies 2018, 11, 1882. [CrossRef]

12. Lee, C.-Y.; Huh, S.-Y. Forecasting Long-Term Crude Oil Prices Using a Bayesian Model with Informative Priors. Sustain. J. Rec. 2017, 9, 190. [CrossRef] 
13. Chai, J.; Cao, P.; Zhou, X.; Lai, K.K.; Chen, X.; Su, S. The Conductive and Predictive Effect of Oil Price Fluctu-ations on China's Industry Development Based on Mixed-Frequency Data. Energies 2018, 11, 1372. [CrossRef]

14. Hsiao, C.Y.-L.; Lin, W.; Wei, X.; Yan, G.; Li, S.; Sheng, N. The Impact of International Oil Prices on the Stock Price Fluctuations of China's Renewable Energy Enterprises. Energies 2019, 12, 4630. [CrossRef]

15. Feng, Y.; Xu, D.; Failler, P.; Li, T. Research on the Time-Varying Impact of Economic Policy Uncertainty on Crude Oil Price Fluctuation. Sustain. J. Rec. 2020, 12, 6523. [CrossRef]

16. Mou, N.; Xie, Y.; Yang, T.; Zhang, H.; Kim, Y.R. The Impact of Slumping Oil Price on the Situation of Tanker Shipping along the Maritime Silk Road. Sustain. J. Rec. 2019, 11, 4796. [CrossRef]

17. Zhao, L.-T.; Liu, L.-N.; Wang, Z.-J.; He, L.-Y. Forecasting Oil Price Volatility in the Era of Big Data: A Text Mining for VaR Approach. Sustain. J. Rec. 2019, 11, 3892. [CrossRef]

18. Jiang, Y.; Ma, C.-Q.; Yang, X.-G.; Ren, Y.-S. Time-Varying Volatility Feedback of Energy Prices: Evidence from Crude Oil, Petroleum Products, and Natural Gas Using a TVP-SVM Model. Sustain. J. Rec. 2018, 10, 4705. [CrossRef]

19. El Anshasy, A. Oil prices and economic growth in oil-exporting countries. In Proceedings of the 32nd international IAEE Conference, San Francisco, CA, USA, 21-24 June 2009.

20. Mendoza, O.; Vera, D. The Asymmetric Effects of Oil Shocks on an Oil-exporting Economy. Cuad. Econ. 2010, 47, 3-13. [CrossRef]

21. Nwani, C.; Orie, J.B. Economic growth in oil-exporting countries: Do stock market and banking sector development matter? Evidence from Nigeria. Cogent Econ. Financ. 2016, 4, 1153872. [CrossRef]

22. Nusair, S.A. The effects of oil price shocks on the economies of the Gulf Co-operation Council countries: Nonlinear analysis. Energy Policy 2016, 91, 256-267. [CrossRef]

23. Sadeghi, A. Oil Price Shocks and Economic Growth in Oil-Exporting Countries: Does the Size of Government Matter? IMF Work. Pap. 2017, 17, 1. [CrossRef]

24. Vohra, R. The Impact of Oil Prices on GCC Economies. Int. J. Bus. Soc. Sci. 2017, 8, 2

25. Alekhina, V.; Yoshino, N. Impact of World Oil Prices on an Energy Exporting Economy Including Monetary Policy; ADBI Working Paper 828; Asian Development Bank Institute: Tokyo, Japan, 2018.

26. Sultan, J.J.S.; Albertus, M.S.; Siti, A.; Tri, R. Oil price and Indonesian economic growth. Probl. Perspect. Manag. 2019, 17, 1. [CrossRef]

27. Balashova, S.; Serletis, A. Oil prices shocks and the Russian economy. J. Econ. Asymmetries 2020, 21, e00148. [CrossRef]

28. Dudian, M.; Mosora, M.; Mosora, C.; Birova, S. Oil Price and Economic Resilience. Romania's Case. Sustain. J. Rec. 2017, 9, 273. [CrossRef]

29. Deng, C.; Jiang, Z.; Sun, C. Estimating the Efficiency and Impacts of Petroleum Product Pricing Reforms in China. Sustain. J. Rec. 2018, 10, 1080. [CrossRef]

30. Farzanegan, M.R.; Markwardt, G. The effects of oil price shocks on the Iranian economy. Energy Econ. 2009, 31, 134-151. [CrossRef]

31. Foudeh, M. The Long Run Effects of Oil Prices on Economic Growth: The case of Saudi Arabia. Int. J. Energy Econ. Policy 2017, 7, 171-192.

32. Fezzani, B.; Nartova, D. Oil Prices Fluctuation Impact on Iraq's Economy. Eur. J. Soc. Sci. 2011, 26, 626-633.

33. Moshiri, S.; Banihashem, A. Asymmetric Effects of Oil Prices hocks on Economic Growth of Oil-Exporting Countries. 2012. Available online: https:/ / papers.ssrn.com/sol3 / papers.cfm?abstract_id=2163306 (accessed on 4 December 2020).

34. Ito, K. The Impact of Oil Price Volatility on Macroeconomic Activityin Russia; Economic Analysis Working Papers; ZBW: Kiel, Germany, 2012; Volume 9.

35. Alkhathlan, K.A. Contribution of oil in economic growth of Saudi Arabia. Appl. Econ. Lett. 2013, 20, 343-348. [CrossRef]

36. Benramdane, A. Oil price volatility and economic growth in Algeria. Energy Sources Part. B Econ. Plan. Policy 2017, 12, 338-343. [CrossRef]

37. Moshiri, S. Asymmetric effects of oil price shocks in oil-exporting countries: The role of institutions. OPEC Energy Rev. 2015, 39, 222-246. [CrossRef]

38. Charfeddine, L.; Barkat, K. Short- And Long-Run Asymmetric Effect of Oil Prices and Oil and Gas Revenues On The Real GDP And Economic Diversification in Oil-dependent Economy. Energy Econ. 2020, 86, 104680. [CrossRef]

39. Abdelsalam, M.A.M. Oil price fluctuations and economic growth: The case of MENA countries. Rev. Econ. Political Sci. 2020. [CrossRef]

40. Benameur, A.G.; Belarbi, Y.; Toumache, R. The Macroeconomic Effects of Oil Prices Fluctuations in Algeria: A SVAR Approach. Les Cah. Cread 2020, 36, 3.

41. Mukhtarov, S.; Aliyev, S.; Zeynalov, J. The Effect of Oil Prices on Macroeconomic Variables: Evidence from Azerbaijan. Int. J. Energy Econ. Policy 2020, 10, 72-80. [CrossRef]

42. Mukhtarov, S.; Mammadov, J.; Ahmadov, F. The Impact of Oil Prices on Inflation: The Case of Azerbaijan. Int. J. Energy Econ. Policy 2019, 9, 97-102. [CrossRef]

43. World Bank (WB). National Accounts Data. 2020. Available online: https://data.worldbank.org/indicator/ (accessed on 14 November 2020).

44. Dickey, D.A.; Fuller, W.A. Likelihood Ratio Statistics for Autoregressive Time Series with a Unit Root. Econometrica 1981, $49,1057$. [CrossRef]

45. Elliott, G.; Rothenberg, T.J.; Stock, J.H. Efficient Tests for an Autoregressive Unit Root. Econometrica 1996, 64, 813. [CrossRef] 
46. Phillips, P.B.; Perron, P. Testing for unit roots in time series regression. Biometrika 1988, 75, 335-346. [CrossRef]

47. Kilian, L. Not all oil price shocks are alike: Disentangling demand and supply shocks in the crude oil market. Am. Econ. Rev. 2009, 99, 1053-1069. [CrossRef]

48. Kilian, L.; Hicks, B. Did Unexpectedly Strong Economic Growth Cause the Oil Price Shock of 2003-2008? J. Forecast. 2013, 32, 385-394. [CrossRef]

49. Kilian, L. Oil Price Shocks: Causes and Consequences. Annu. Rev. Resour. Econ. 2014, 6, 133-154. [CrossRef]

50. Chen, H.; Liu, L.; Wang, Y.; Zhu, Y. Oil Price Shocks and U.S. dollar Exchange Rates. Energy 2016, 112, 1036-1048. [CrossRef]

51. Kiliçarslan, Z.; Dumrul, Y. Macroeconomic Impacts of Oil Price Shocks: An Empirical Analysis Based on The SVAR Models. Rev. Econ. 2017, 69, 55-72.

52. Li, L.; Yin, L.; Zhou, Y. Exogenous shocks and the spillover effects between uncertainty and oil price. Energy Econ. 2016, 54, 224-234. [CrossRef]

53. Adedokun, A. The effects of oil shocks on government expenditures and government revenues nexus in Nigeria (with exogeneity restrictions). Futur. Bus. J. 2018, 4, 219-232. [CrossRef]

54. Mukhtarov, S.; Humbatova, S.; Seyfullayev, I. The impact of bank credits on non-oil GDP: Evidence from Azerbaijan. Banks Bank Syst. 2019, 14, 120-127. [CrossRef]

55. Mukhtarov, S.; Yüksel, S.; Ibadov, E.; Hamidov, H. The effectiveness of exchange rate channel in Azerbaijan: An empirical analysis. Banks Bank Syst. 2019, 14, 111-121. [CrossRef]

56. Mackinnon, J.G. Numerical Distribution Functions for Unit Root and Cointegration Test. J. Appl. Econom. 1996, 11, 601-618. [CrossRef]

57. Zivot, E.; Andrews, D.W.K. Further Evidence on the Great Crash, the Oil-Price Shock, and the Unit-Root Hypothesis. J. Bus. Econ. Stat. 1992, 10, 251.

58. The International Energy Agency-IEA, Azerbaijan Energy Profile, 2020. Available online: https://www.iea.org/reports/ azerbaijan-energy-profile (accessed on 4 December 2020).

59. Humbatova, S.I.; Hajiyev, N.Q.-O. Oil Factor in Economic Development. Energies 2019, 12, 1573. [CrossRef]

60. Mukhtarov, S.; Mikayilov, J.I.; Humbatova, S.; Muradov, V. Do High Oil Prices Obstruct the Transition to Renewable Energy Consumption? Sustainability 2020, 12, 4689. [CrossRef]

61. The Central Bank of Republic of Azerbaijan. 2020. Available online: https://www.cbar.az/page41/macroeconomic-indicators (accessed on 14 November 2020).

62. Mukhtarov, S.; Humbatova, S.; Hajiyev, N.G.-O.; Aliyev, S. The Financial Development-Renewable Energy Consumption Nexus in the Case of Azerbaijan. Energies 2020, 13, 6265. [CrossRef]

63. Hasanov, F. Analyzing Price Level in a Booming Economy: The Case of Azerbaijan. SSRN Electron. J. 2011. [CrossRef]

64. Hasanov, F. Dutch disease and the Azerbaijan economy. Communist Post-Communist Stud. 2013, 46, 463-480.

65. Zulfigarov, F.; Neuenkirch, M. The impact of oil price changes on selected macroeconomic indicators in Azerbaijan. Econ. Syst. 2020, 44. [CrossRef] 